\title{
ENSO-cave drip water hydrochemical relationship: a 7-year dataset from south-eastern Australia
}

\author{
Carol V. Tadros ${ }^{1,2}$, Pauline C. Treble ${ }^{1,2}$, Andy Baker ${ }^{2}$, Ian Fairchild ${ }^{3,4}$, Stuart Hankin $^{1}$, Regina Roach ${ }^{5}$, \\ Monika Markowska $^{1,2}$, and Janece McDonald ${ }^{6}$ \\ ${ }^{1}$ Australian Nuclear Science and Technology Organisation, Locked Bag 2001, Kirrawee DC, NSW 2232, Australia \\ ${ }^{2}$ Connected Waters Initiative Research Centre, UNSW Australia, Kensington NSW 2052, Australia \\ ${ }^{3}$ School of Geography, Earth and Environmental Sciences, University of Birmingham, Edgbaston, Birmingham, UK \\ ${ }^{4}$ Birmingham Institute for Forest Research, University of Birmingham, Edgbaston, Birmingham, UK \\ ${ }^{5}$ NSW National Parks and Wildlife Service, Sydney, NSW, Australia \\ ${ }^{6}$ Environmental and Climate Change Research Group, School of Environmental and Life Sciences, University of Newcastle, \\ Callaghan, NSW 2308, Australia
}

Correspondence to: Carol V. Tadros (carol.tadros@ansto.gov.au)

Received: 28 April 2016 - Published in Hydrol. Earth Syst. Sci. Discuss.: 2 June 2016

Revised: 20 October 2016 - Accepted: 25 October 2016 - Published: 17 November 2016

\begin{abstract}
Speleothems (cave deposits), used for palaeoenvironmental reconstructions, are deposited from cave drip water. Differentiating climate and karst processes within a drip-water signal is fundamental for the correct identification of palaeoenvironmental proxies and ultimately their interpretation within speleothem records. We investigate the potential use of trace element and stable oxygen-isotope $\left(\delta^{18} \mathrm{O}\right)$ variations in cave drip water as palaeorainfall proxies in an Australian alpine karst site. This paper presents the first extensive hydrochemical and $\delta^{18} \mathrm{O}$ dataset from Harrie Wood Cave, in the Snowy Mountains, south-eastern (SE) Australia. Using a 7-year long rainfall $\delta^{18} \mathrm{O}$ and drip-water $\mathrm{Ca}, \mathrm{Cl}$, $\mathrm{Mg} / \mathrm{Ca}, \mathrm{Sr} / \mathrm{Ca}$ and $\delta^{18} \mathrm{O}$ datasets from three drip sites, we determined that the processes of mixing, dilution, flow path change, carbonate mineral dissolution and prior calcite precipitation (PCP) accounted for the observed variations in the drip-water geochemical composition. We identify that the three monitored drip sites are fed by fracture flow from a well-mixed epikarst storage reservoir, supplied by variable concentrations of dissolved ions from soil and bedrock dissolution. We constrained the influence of multiple processes and controls on drip-water composition in a region dominated by El Niño-Southern Oscillation (ENSO). During the El Niño and dry periods, enhanced PCP, a flow path change and dissolution due to increased soil $\mathrm{CO}_{2}$ production occurred in response to warmer than average tem-
\end{abstract}

peratures in contrast to the La Niña phase, where dilution dominated and reduced PCP were observed. We present a conceptual model, illustrating the key processes impacting the drip-water chemistry. We identified a robust relationship between ENSO and drip-water trace element concentrations and propose that variations in speleothem $\mathrm{Mg} / \mathrm{Ca}$ and $\mathrm{Sr} / \mathrm{Ca}$ ratios may be interpreted to reflect palaeorainfall conditions. These findings inform palaeorainfall reconstruction from speleothems regionally and provide a basis for palaeoclimate studies globally, in regions where there is intermittent recharge variability.

\section{Introduction}

The El Niño-Southern Oscillation (ENSO) is the leading mode of rainfall variation in south-eastern (SE) Australia (Dai et al., 1997), where extreme events of rainfall variability, such as droughts, floods, bush fires and cyclones associated with ENSO, are prominent (Risbey et al., 2009). Severe drought between 2001 and 2008 and enhanced El Niño conditions resulted in record low inflows from the alpine headwaters of the Murray River (Murphy and Timbrel, 2008; Cai and Cowan, 2008; Nicholls, 2010), strongly impacting the water resource availability of the Murray-Darling basin and agricultural production, affecting the livelihood of ur- 
ban and rural Australians (Barros and Bowden, 2008; McGowan et al., 2009). Reconstructing past ENSO variability from speleothems (calcium carbonate cave deposits) located within the Yarrangobilly Caves system in the Snowy Mountains alpine region will provide a basis for understanding future regional impacts, therefore assisting with water resource management policy making and the global impacts that ENSO-driven climate variability has on the environment, agricultural production, water resources, ecosystems as well as on human life, emergency management and disease (Power and Smith, 2007).

Studies have shown that trace element time series constructed from the central growth axis of a speleothem provide potential proxy evidence of palaeorainfall conditions (Roberts et al., 1998; Lauritzen et al., 1999; Fairchild et al., 2001; Johnson et al., 2006; Cruz et al., 2007; Jo et al., 2010). The concentration of trace elements in drip water is dependent on the evolution of the drip-water geochemistry, which is influenced by site-specific characteristics (Spötl et al., 2005) and a range of surface and karst processes (Baldini et al., 2006). Elements may be atmospherically derived from meteoric precipitation $(P)$, dust supply (Goede et al., 1998; Dredge et al., 2013), marine aerosols (Baker et al., 2000; Fairchild et al., 2000), volcanic eruption activity (Frisia et al., 2005, 2008), atmospheric pollutants (Spötl et al., 2005; Wynn et al., 2008), the host rock and soil (Tooth and Fairchild, 2003). Surface processes: deforestation (Borsato et al., 2007) and fire (Coleborn et al., 2016; Nagra et al., 2016); soil processes: water-sediment and water-rock interaction (Fairchild et al., 2000), colloid, particle or solute mobilization (Hartland et al., 2012), and temperature, water availability and $\mathrm{CO}_{2}$ changes (Cuthbert et al., 2014; Rutlidge et al., 2014; Treble et al., 2016); and karst hydrological processes: hydrological flow routes, mixing and dilution effects, degassing and calcite precipitation, differential and incongruent dissolution, and selective leaching (Fairchild et al., 2000; Tooth and Fairchild, 2003) potentially modulate the concentration of elements in the drip water. Constraining these processes and understanding potential climatic signals in the hydrochemistry of drip water is quintessential in successfully using trace elements as a palaeoclimate proxy (Fairchild et al., 2006).

As such, long-term datasets of stable oxygen-isotope $\left(\delta^{18} \mathrm{O}\right)$ and geochemistry (trace element concentrations and ratios) of rainfall and cave drip water provide an empirical basis for identifying factors influencing trace element variability ultimately recorded in speleothems (Baldini et al., 2002; Treble et al., 2003; Riechelmann et al., 2011; Oster et al., 2012; Frappier, 2013; Partin et al., 2013). For example, McDonald et al. (2004) demonstrated $\mathrm{Mg} / \mathrm{Ca}$ and $\mathrm{Sr} / \mathrm{Ca}$ ratios in the drip water doubled in response to an El Niño event that occurred during a 2.5-year baseline monitoring study at Wombeyan Caves, SE Australia. This was an important finding that raised the potential for using speleothem records to reconstruct past ENSO variability for this region.
The Wombeyan Caves site lies in the Sydney catchment. The study site used here lies $\sim 85 \mathrm{~km}$ away in the headwaters of the Murray-Darling basin and as such provides an opportunity to further examine the ENSO signal in cave drip water at a second site from this region, with a longer dataset. Additionally, the interpretation of this new hydrochemical dataset is conducted within an established framework. The dominant controls on precipitation stable isotope variability in this alpine region have been examined. Callow et al. (2014) conducted event-based $\delta^{18} \mathrm{O}$ precipitation (rainfall and snow) sampling across 18 sites ( $n=70$; from February 2010 to March 2012) from a transect in the Snowy Mountains; they determined that the origin of moisture, pathway and terrain effects were the dominant controls on precipitation stable isotope variability in this alpine region. Furthermore, the unsaturated zone hydrology of our studied cave has been investigated. Markowska et al. (2015) presented rainfall, soil moisture saturation and drip discharge data at 14 sites within the same cave studied here, between October 2011 and January 2013. Markowska et al. (2015) applied a statistical approach to classify the drip types and identified five flow regimes, which were represented using a combined conceptual flow and box hydrological model.

The emphasis of this study is to understand the relationship between modern climatic and environmental controls on the cave drip water in a region strongly influenced by ENSO, to aid in the interpretation of speleothem-based palaeoenvironmental records and ultimately to develop climate proxy records from suitable speleothems (Tooth and Fairchild, 2003). Here we present the first comprehensive climate and drip water monitoring study, which commenced at three drip sites in 2006, in Harrie Wood Cave (Yarrangobilly, New South Wales, Australia). This record encapsulated the last 3 years of the "Millennium Drought" (1997-2009), which had a large impact across SE Australia (CSIRO and BoM, 2015) and the 2010/2011 La Niña event, which produced widespread flooding across SE Australia (CSIRO and BoM, 2015). Within this framework, spanning 7 years, we employed the results to ascertain the key hydrological processes that control the drip hydrochemistry during La Niña and El Niño events and categorized the flow regime. Our findings form the basis for palaeoclimate interpretation of speleothem trace element and $\delta^{18} \mathrm{O}$ records located within the Yarrangobilly Caves system and are pertinent for speleothem palaeoclimate research in other ENSO-dominated regions globally.

\section{Study area}

\subsection{Study site and climate}

Harrie Wood Cave $\left(35^{\circ} 44^{\prime} \mathrm{S}, 148^{\circ} 30^{\prime} \mathrm{E}\right)$ is located in a limestone belt ca. $14 \mathrm{~km}$ long and $1.5 \mathrm{~km}$ wide along the Yarrangobilly River in the north of Kosciuszko National Park, New South Wales, Australia (Fig. 1a). The Yarrangobilly 

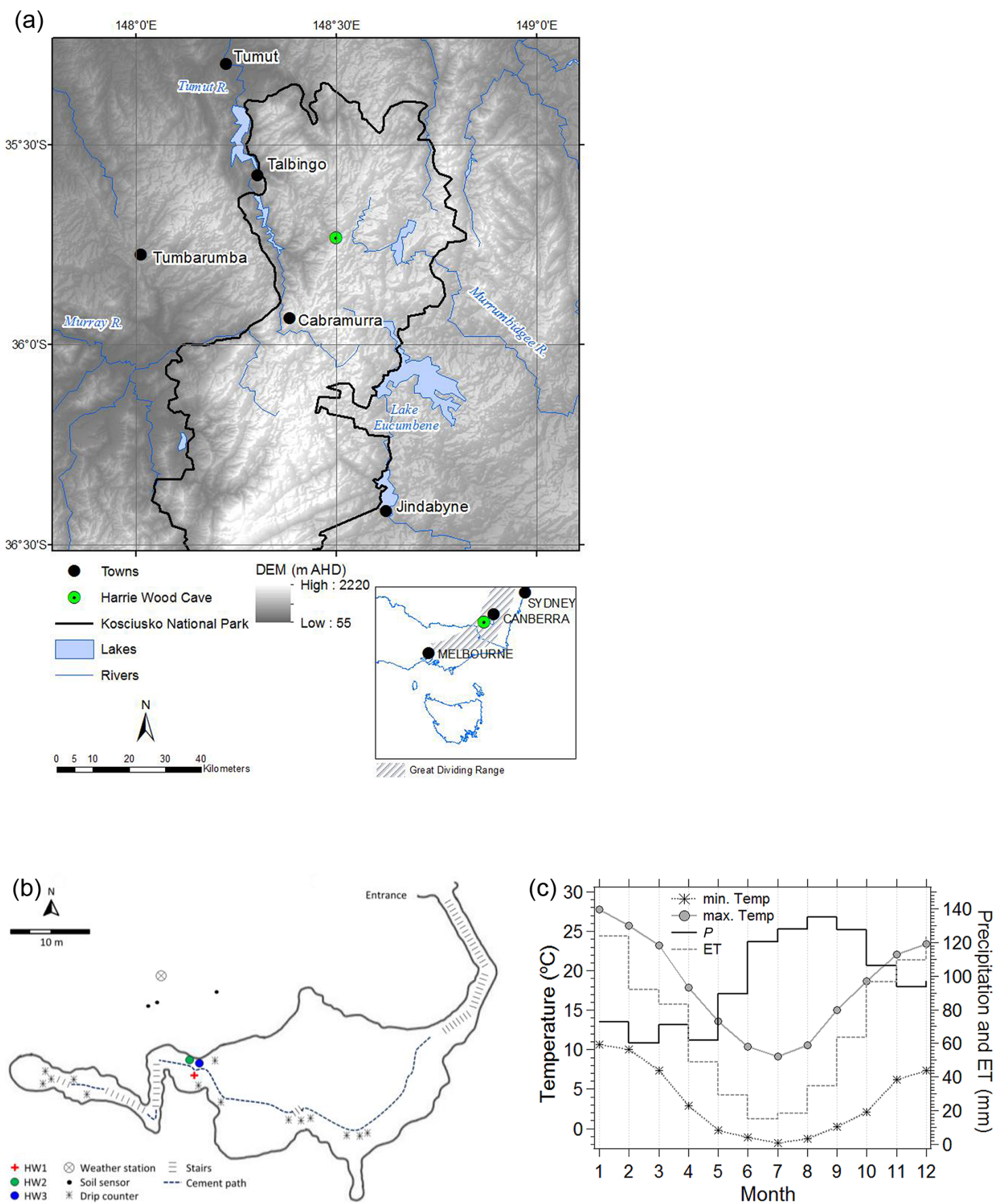

Figure 1. (a) Location of Harrie Wood Cave, Snowy Mountains, Australia. (b) Survey map of the Harrie Wood Cave system (adapted from Nicholl, 1974) showing location of the three drip-water sites (HW1-3), which have been monitored since 2006, the location of automatic drip counters underneath 14 drip sites reported by Markowska et al. (2015), and overlayed is the location of the weather station and Stevens Hydra Probe ${ }^{\circledR}$ soil sensors. (c) Site monthly mean air temperature $\left({ }^{\circ} \mathrm{C}\right)(2006-2013)$, precipitation (mm) (1983-2013) and ET; the sum of transpiration and soil evaporation (1967-1990; parameter $F_{\mathrm{WE}}\left(\mathrm{m} \mathrm{day}^{-1}\right)$ compiled by the WaterDyn model, from the Australian Water Availability Project (AWAP) database; Raupach et al., 2009, 2011).

Limestone formed in the upper Silurian period from a coral reef (Worboys, 1982). Harrie Wood Cave is located within the Yarrangobilly Caves system, which includes over 250 independent limestone caves that began to develop in the
Pleistocene (Worboys, 1982). Harrie Wood Cave is hosted within a highly fractured hard massive limestone and the drip sites are in close proximity to a fracture contact zone. The host limestone bedrock contains red/brown palaeokarst 
features and little to no dolomite. The cave entrance is ca. $965 \mathrm{~m}$ above sea level (a.s.l.) on a north-dipping steep rocky gorge. Harrie Wood is a restricted access, medium-sized south-dipping cave. The cave chamber is $80 \pm 2 \mathrm{~m}$ in length and $34 \pm 1 \mathrm{~m}$ deep (Nicholl, 1974).

Surrounding vegetation consists of open snow gum (Eucalyptus pauciflora subsp. Pauciflora) and black sallee (E. stelullata) woodland dominated by a snow grass (Poa sieberi) understorey (Aplin et al., 2010). Above the cave, vegetation coverage is sparsely developed on shallow rocky soil that lacks clearly defined horizons, and are dominated by angular clasts (typically $2-10 \mathrm{~cm}$ size) indicating mechanical weathering processes. The surface over the cave was burnt by an intense wildfire in 2003 and the shrubby vegetation that is present over the cave shows evidence of regeneration post-fire (Coleborn, 2016). There is no evidence of a distinct zone of infiltration on the surface directly above and upslope of Harrie Wood Cave. There is also no evidence of surface runoff following rain events. We interpret from our field observations that infiltration is via pervasive cracks and fissures.

The Yarrangobilly Caves system is part of the Australian Alps bioregion and is dominated by a montane climate (Stern et al., 2000), being characterized by mild dry summers and cold wet winters (Fig. 1c). The median annual rainfall at the Bureau of Meteorology (BoM) weather station at Yarrangobilly Caves (BoM station 72141), calculated using the climatological median $1985-2013$, is $1178 \pm 29 \mathrm{~mm}$ with a winter maximum of $349 \pm 15 \mathrm{~mm}$. The two dominant synoptic weather categories delivering most of this cool-season rainfall to SE Australia are cut-off low-pressure systems out of the westerlies and systems from the mid-latitudes including mid-latitude storms and fronts (Chubb et al., 2011; Pook et al., 2014; Callow et al., 2014). Modelled total evapotranspiration (ET) is maximum in summer and minimum in winter, and mean annual ET is $838 \pm 40 \mathrm{~mm}$ over the period $1961-$ 1990. The site has a mean annual temperature of $10.5^{\circ} \mathrm{C}$, with mean maximum temperatures in January and mean minimum temperatures in July of 27.8 and $-1.8^{\circ} \mathrm{C}$, respectively. The growing season is limited by cold winter temperatures.

\subsection{Drip site setting}

The three drip-water monitoring sites (HW1-3) in this study are measured from active stalactites (Table 1) located centrally within the cave (Fig. 1b) at a depth of $38 \mathrm{~m}$ to the surface. HW1 and 2 were feeding actively forming stalagmites ca. $0.5 \mathrm{~m}$ apart on either side of the main path. These stalagmites were removed for palaeoclimate studies in 2006. In order to remove HW2, a small adjacent calcite column that had formed from a fused stalactite-stalagmite pair ca. 10$15 \mathrm{~cm}$ from HW2 (see Supplement S1 for photograph), had to be removed also. This resulted in re-invigoration of the drip point that had formed the column, which we included in our sampling program and refer to here as HW3.
Table 1. Summary of the drip-point characteristics for the monitoring sites.

\begin{tabular}{ll}
\hline Site & Description \\
\hline HW1 & $\begin{array}{l}\text { The tip of the } 1 \text { m long massive stalactite }(130 \mathrm{~mm} \text { wide) } \\
\text { was broken, presumably when the path was constructed } \\
\text { in } \sim 1911 \mathrm{CE} \text {. A } 7 \mathrm{~cm} \text { long soda-straw stalactite has } \\
\text { formed from the base of the massive stalactite and } \\
\text { drips onto a } 14 \mathrm{~cm} \text { tall and } 8 \mathrm{~cm} \text { wide stalagmite } \\
\text { developed on a flowstone on pebble ground. } \\
\text { The stalagmite was removed in } 2006 .\end{array}$ \\
\hline HW2 & $\begin{array}{l}\text { Drip emanates from a } 1 \mathrm{~m} \text { long, } 110 \text { mm wide stalactite. } \\
\text { The } 160 \text { mm by } 70 \text { mm stalagmite was removed in } 2006 .\end{array}$ \\
& $\begin{array}{l}\text { HW2 is an overflow of HW3 (see Supplement S1 } \\
\text { and Sect. } 5.1 \text { for further discussion). }\end{array}$ \\
\hline HW3 & $\begin{array}{l}\text { Drip point formed when stalagmite from site HW2 } \\
\text { was removed. }\end{array}$ \\
\hline
\end{tabular}

Unsaturated zone hydrology of Harrie Wood Cave has recently been characterized (Markowska et al., 2015) and 5 drip-water regimes were identified. All flow types are fed by a theoretical soil storage and epikarst storage reservoir by fracture/fissure drainage. The five discharge flow types are as follows. Type 1 is designated mixed-flow/storage connectivity (low flow/high flow). Water at these discharge points is drained from a bulk homogenized epikarst storage reservoir. At the high-flow sub-type, during periods of water excess, the epikarst store is bypassed and water is routed directly from the soil storage reservoir. At the low-flow sub-type, discharge is from a pocket reservoir with a variable head within the epikarst storage reservoir. With Type 2 extreme events activated drip sites, a large intense infiltration event is required to initiate flow from the epikarst store. Type 3 are overflow sites, with discharge at the drip point fed by overflow from the pocket reservoir. Type 4 are non-linear flow sites; based on intra-karst dynamics, flow is intermittent between both storage reservoirs. Type 5 are underflow sites; during high infiltration, discharge is preferential underflow where both reservoirs are bypassed, and during base-flow conditions flow is sourced from the epikarst store. The sampling points in this study, HW1-3, are situated within the transect monitored by Markowska et al. (2015) (Fig. 1b).

\section{Methods}

\subsection{Meteorological data}

Daily rainfall was measured from the BoM standard $203 \mathrm{~mm}$ rain gauge at 09:00 local time (LT) each morning. Provided precipitation was $2 \mathrm{~mm}$ or greater, an aliquot of this precipitation was collected in a $10 \mathrm{~mL}$ amber bottle, ensuring zero headspace, and stored for stable isotope analysis $\left(\delta^{18} \mathrm{O}, \delta^{2} \mathrm{H}\right)$. Maximum and minimum air temperatures are also recorded at 09:00 LT using BoM standard procedures. 
A network of two automatic weather stations were installed above Harrie Wood and Jillabenan Caves on the 14 October 2011 and 6 September 2012, respectively. Atmospheric measurements of pressure, humidity, rainfall, temperature and wind speed and direction are recorded by a Davis Vantage Pro $2^{\mathrm{TM}}$. Within the soil zone above each cave system, soil sensor probes were installed and buried in holes drilled with an auger to a depth of $25-30 \mathrm{~cm}$ at three localities (Fig. 1b). The Stevens Hydra Probe ${ }^{\circledR}$ soil sensor measurements include temperature, soil moisture and electrical conductivity and complex dielectric permittivity (both corrected from 0 to $35^{\circ} \mathrm{C}$ ). All data are recorded every $15 \mathrm{~min}$ by a dataTaker DT80 data logger. A detailed description of the parameters measured by the various instrumentation and data available from the network are outlined in Supplement S2.

\subsection{Geochemistry}

Drip water analysed for this study was collected approximately fortnightly over the period July 2006 to December $2013(n=468)$. The drip rate was measured manually as the time interval elapsed between two drips recorded using a stopwatch and the drips emanating from the stalactites accumulated in 1 L HDPE containers. Since March 2011 and sample volume permitting, in situ field measurements of electrical conductivity (referred to $25^{\circ} \mathrm{C} ; \pm 1 \%$ ), temperature $\left( \pm 0.1^{\circ} \mathrm{C}\right)$ and $\mathrm{pH}$ measurements $( \pm 0.01 \mathrm{pH})$ were made using a TPH1-MyronL TechPro II handheld meter, which was calibrated using buffer solutions that were kept at cave temperature.

At each drip site, aliquots from the bulk water sample were collected and filtered through a mixed cellulose ester $0.45 \mu \mathrm{m}$ filter and split into (i) two clean $50 \mathrm{~mL}$ polypropylene bottles for cation and anion analysis and (ii) a $10 \mathrm{~mL}$ amber glass bottle for $\delta^{18} \mathrm{O}$ and $\delta^{2} \mathrm{H}$ analysis. On exiting the cave, samples were refrigerated, transported to the laboratory in an insulated container and maintained at $4{ }^{\circ} \mathrm{C}$ until analysis.

Cation and anion analysis was conducted at the Environmental Research Chemistry Laboratory at the Australian Nuclear Science and Technology Organisation (ANSTO). Cation analysis was carried out on a $\operatorname{Varian}^{\mathrm{TM}}$ Vista Pro AX ICP-AES; prior to analysis aliquots were acidified with $1 \%$ $\mathrm{HNO}_{3}$. Anion analysis was conducted on an un-acidified aliquot using a Dionex 600 Instrument with an auto suppressor. Analytical error on cation and anion analyses was $\leq 5 \%$.

Representative limestone samples $(n=7)$ were collected from bedrock exposures above the cave and within Harrie Wood Cave. Freshly cleaved samples were dried at $40^{\circ} \mathrm{C}$ and powdered using a ROCKLABS ${ }^{\circledR}$ TC-40 tungsten carbide ball mill. Then, $0.2 \mathrm{~g}$ of sample was microwave digested at $180{ }^{\circ} \mathrm{C}$ for $15 \mathrm{~min}$ using aqua regia $\left(\mathrm{HCl} / \mathrm{HNO}_{3}=1: 3\right)$ and analysed by ICP-AES at the Environmental Research Chemistry Laboratory at ANSTO.

The isotopic composition $\left(\delta^{18} \mathrm{O}\right.$ and $\left.\delta^{2} \mathrm{H}\right)$ of the rainfall and drip-water samples were performed on a LGR-
$24 \mathrm{~d}$ off-axis, integrated cavity output, cavity ringdown mass spectrometer at University of New South Wales (UNSW) Australia. $\delta^{18} \mathrm{O}$ and $\delta^{2} \mathrm{H}$ values are reported relative to $\mathrm{V}$ SMOW2. Analytical precision for $\delta^{18} \mathrm{O}$ is 0.17 and $0.6 \%$ for $\delta^{2} \mathrm{H}$.

\subsection{Mixing and prior calcite precipitation calculations}

To determine whether the geochemical evolution of the drip water was principally due to prior calcite precipitation (PCP), the hydrochemistry was assessed based on the accepted mathematical methods after Sinclair et al. (2012) and Tremaine and Froelich (2013). First, to compare between the two methods, $\ln (\mathrm{Sr} / \mathrm{Ca})\left(\mathrm{mmol} \mathrm{mol}^{-1}\right)$ vs. $\ln (\mathrm{Mg} / \mathrm{Ca})$ $\left(\mathrm{mmol} \mathrm{mol}^{-1}\right)$ ratios in dissolved host bedrock endmembers overlayed with the drip-water ratios was graphed. The $\mathrm{Mg} / \mathrm{Ca}$ and Sr / Ca ratios during the step change in 2007, wet period and high dry-season Ca values were differentiated from the complete dataset to isolate processes affecting the drip-water chemical evolution during these periods. Then, at each drip site the slopes of the linear regression of the $\ln (\mathrm{Sr} / \mathrm{Ca})$ vs. $\ln (\mathrm{Mg} / \mathrm{Ca})$ (weight ratio) graph was calculated based on the model suggested by Sinclair et al. (2012), where a slope of $0.709-1.003$ is an indicator of water-rock interactions, i.e. PCP and incongruent dissolution-driven processes.

\section{Results}

\subsection{Bedrock composition}

The $\mathrm{Ca}$ concentration and $\mathrm{Mg} / \mathrm{Ca}$ and $\mathrm{Sr} / \mathrm{Ca}$ ratios for the suite of bedrock samples are listed in Table 2. Bedrock $\mathrm{Mg} / \mathrm{Ca}$ ratios range from 2.6 to $15.3 \mathrm{mmol} \mathrm{mol}^{-1}$ and $\mathrm{Sr} / \mathrm{Ca}$ ratios lie between 0.03 and $0.32 \mathrm{mmol} \mathrm{mol}^{-1}$. These low ratios indicate the host limestone rock above and within Harrie Wood Cave are a low-Mg calcite type, indicating diagenesis of the original bedrock material. We observe three groupings of samples; Ca does not vary significantly between the samples but there is an observed difference in the $\mathrm{Mg} / \mathrm{Ca}$ and $\mathrm{Sr} / \mathrm{Ca}$ ratios between groups. The ratios for samples (R7-R10) are similar and there is no difference between colour variations, the limestone conglomerate (R12) has the highest $\mathrm{Mg} / \mathrm{Ca}$ ratio and the palaeokarst samples (R13, R14) have the lowest $\mathrm{Mg} / \mathrm{Ca}$ and $\mathrm{Sr} / \mathrm{Ca}$ ratios.

\subsection{Precipitation and infiltration}

The observed daily rainfall and monthly cumulative water balance (CWB) at the study site and the Southern Oscillation Index (SOI) are shown in Fig. 2. The CWB represents a residual mass curve to show trends in the cumulative monthly water budget trends, following the method of Hurst (1951). It is calculated as the cumulative sum of the monthly $P$-ET anomalies from the climatological mean (1961-1990). The 


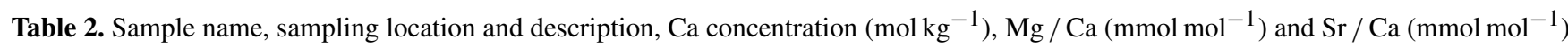
ratios in bedrock samples. On the slope above Harrie Wood Cave, representative samples were collected from the soil surface. The outcrop above the cave is located $33 \mathrm{~m}$ west of the cave entrance along the path and at the base of the slope. Within the cave, only exposed limestone surfaces were sampled. Colours of samples are based on a visual comparison with the Munsell ${ }^{\circledR}$ rock-colour chart.

\begin{tabular}{|c|c|c|c|c|}
\hline Sample name & Sampling location: description, colour & $\begin{array}{r}\mathrm{Ca} \\
\left(\mathrm{mol} \mathrm{kg}^{-1}\right)\end{array}$ & $\begin{array}{r}\mathrm{Mg} / \mathrm{Ca} \\
\left(\mathrm{mmol} \mathrm{mol}^{-1}\right)\end{array}$ & $\begin{array}{r}\mathrm{Sr} / \mathrm{Ca} \\
\left(\mathrm{mmol} \mathrm{mol}^{-1}\right)\end{array}$ \\
\hline YGB_R7 & $\begin{array}{l}\text { Slope above Harrie Wood Cave: } 21 \mathrm{~cm} \text { weathered } \\
\text { limestone boulder, very light grey, } \\
\text { contains moderate orange pink patches }\end{array}$ & 10.0 & 11.7 & 0.27 \\
\hline YGB_R8 & $\begin{array}{l}\text { Outcrop above Harrie Wood Cave: } \\
\text { limestone, greyish black }\end{array}$ & 10.2 & 11.5 & 0.32 \\
\hline YGB_R9 & $\begin{array}{l}\text { Harrie Wood Cave, lower chamber: } \\
\text { limestone, moderate reddish orange }\end{array}$ & 9.7 & 9.9 & 0.23 \\
\hline YGB_R10 & $\begin{array}{l}\text { Harrie Wood Cave, lower chamber: } \\
\text { limestone, medium dark grey }\end{array}$ & 9.7 & 8.8 & 0.24 \\
\hline YGB_R12 & $\begin{array}{l}\text { Slope above Harrie Wood Cave: limestone, } \\
\text { conglomeratic - round very light grey fragments } \\
\text { over } 2 \mathrm{~mm} \text {, cemented by moderate yellow finer material }\end{array}$ & 7.5 & 15.3 & 0.18 \\
\hline YGB_R13 & & 10.3 & 2.6 & 0.08 \\
\hline YGB_R13 (duplicate) & $\begin{array}{l}\text { Inception horizon along bedding plane in outcrop above } \\
\text { Harrie Wood Cave: palaeokarst, moderate reddish brown }\end{array}$ & $\begin{array}{r}10.2 \\
87\end{array}$ & 2.6 & 0.08 \\
\hline YGB_R14 & & 8.7 & 3.8 & 0.03 \\
\hline
\end{tabular}

earlier half of the record overlaps the latter 4 years of the "Millennium Drought", including SE Australia's most persistent rainfall deficit that occurred between 1997 and 2009 (CSIRO and BoM, 2015). Hence, the site experienced belowaverage rainfall from 2006 to 2009, and for much of the preceding decade. For example, from May 06 to December 06 (Fig. 3a), annual rainfall totals were $52.6 \%$ below the mean attributable to a weak El Niño event (BoM, 2015a). The years 2007-2009 were a period of generally dry conditions, where the annual total precipitation was on average $10.3 \%$ below the 30 -year average. There were exceptions of above-average monthly rainfall for February and May 2007, November 2007 to April 2008, July 2008 and in April, July and September 2009 (Fig. 3b; BoM, 2015b). However, the reduced annual totals until 2010 resulted in a decline in the calculated cumulative water balance (Fig. 2b).

By contrast, in 2010-2012, average annual rainfall at Yarrangobilly Caves (BoM station 72141) was 152, 135 and $115 \%$ above the mean for these 3 years, due to the strong 2010-2012 La Niña event (BoM, 2015a). The wettest interval in our study occurred from July 2010 to March 2011 (Figs. 2b and 3c) during which the calculated cumulative water balance increased (Fig. 2b). The subsequent 6 months from May to October 2011 were relatively dry (Fig. 3d), followed by a 5-month period of above-average monthly rainfall from November 2011 to March 2012 (Fig. 3e).

Based on measurements of soil moisture saturation between 14 October 2011 and 9 January 2013, Markowska et al. (2015) interpreted that a daily rainfall threshold range between 13 and $31.4 \mathrm{~mm}$ for Harrie Wood Cave was required to initiate a discharge response at 14 monitored drip sites. During the drier 2006 to mid-2010 period of our study, there were 75 such events in total, representing $30 \%$ of total rain days. By contrast, during the wetter mid-2010 to 2014 interval, there were 124 events, representing $37 \%$ of rain days.

\subsection{Variability of $\delta^{18} \mathrm{O}$ in precipitation and drip water}

Daily rainfall, $\delta^{18} \mathrm{O}$, monthly precipitation-weighted mean (PWM), as well as drip-water $\delta^{18} \mathrm{O}$, are shown in Fig. 2. The monthly $\mathrm{PWM}$ of rain water $\delta^{18} \mathrm{O}$ values ranges from -13.6 to $-2.1 \%$ over the sampling period, with an overall $\delta^{18} \mathrm{O}$ PWM of $-6.9 \%$ of all rainfall events. At Harrie Wood Cave, rainfall events greater than $13 \mathrm{~mm}$ initiate recharge (Markowska et al., 2015); the $\delta^{18} \mathrm{O}$ PWM value from these recharge events $(-6.7 \%$ ) is not significantly different than that of all rainfall events. The monthly $\delta^{18} \mathrm{O}$ PWM values show a large $5-10 \%$ intra-annual variation following the general seasonal trend of depleted isotopic values in winter and isotopically enriched values in summer, although the winter isotopic depletion is much less pronounced in 2008, 2009 and 2011. During the dry period prior to mid-2010, the PWM was enriched (-6.2\%o) compared to the $2010 / 2012$ wet period $(-6.9 \%)$.

With regards to drip water, there is ca. $0.5-1 \%$ variability over the observation period, which is largely dampened com- 


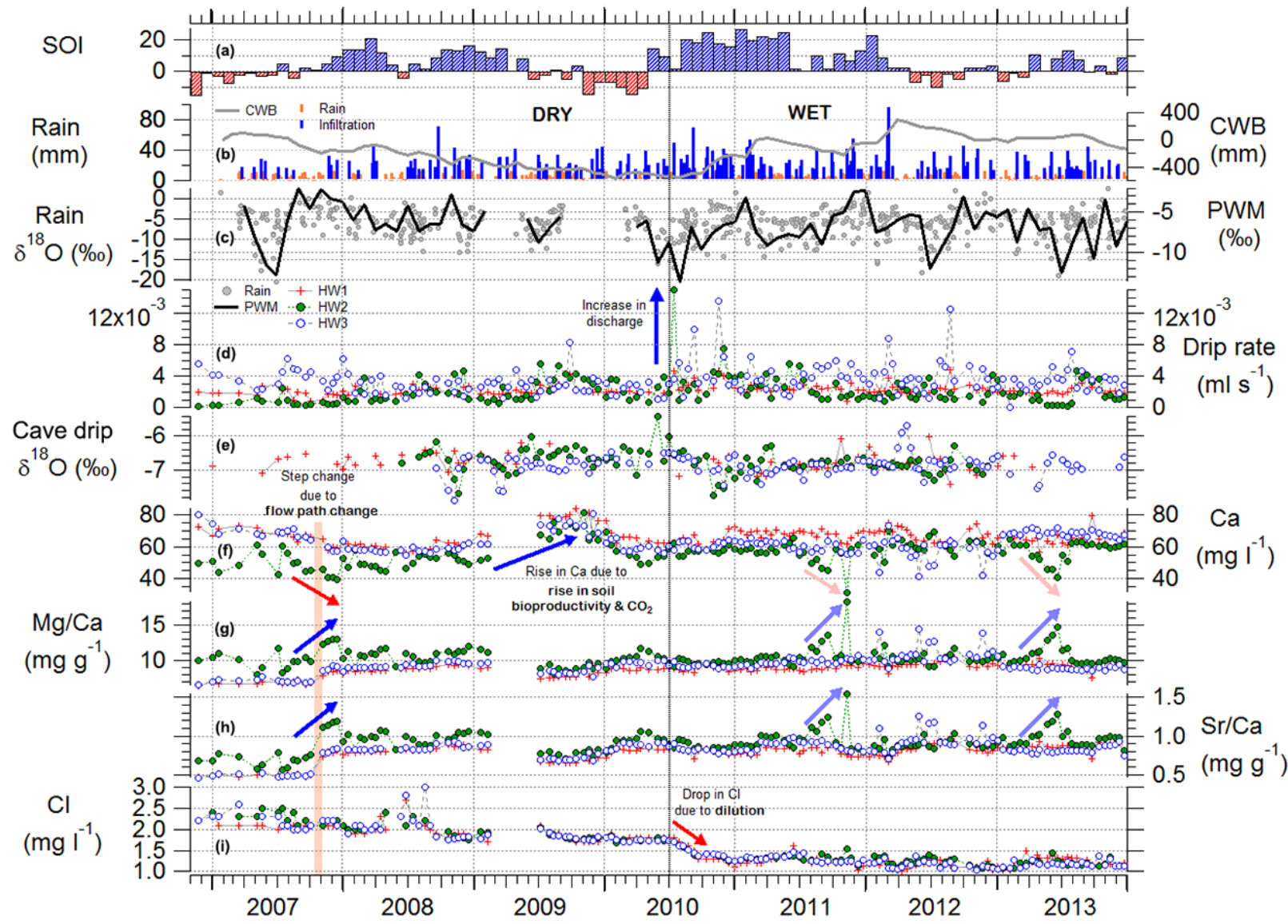

Figure 2. The combined time series of (a) SOI as a measure of ENSO, (b) daily rainfall (BoM), infiltration corresponding to when rainfall exceeds $13 \mathrm{~mm}$, and cumulative water balance $(\mathrm{CWB}),(\mathbf{c})$ daily $\delta^{18} \mathrm{O}_{\text {rain }}$ overlayed with the monthly precipitation-weighted mean $(\mathrm{PWM})$, (d) drip rate, (e) $\delta^{18} \mathrm{O}_{\text {dripwater }}$, (f) $\mathrm{Ca},(\mathbf{g}) \mathrm{Mg} / \mathrm{Ca}$, (h) $\mathrm{Sr} / \mathrm{Ca}$ and (i) $\mathrm{Cl}$ at drip site $\mathrm{HW} 1-3$. Gaps within a time series indicate no available data. The dotted vertical line at July 2010 signifies the onset of the wet period. Blue and red arrows indicate an increase and decrease respectively. The pink vertical bar highlights the step change due to a flow path change.

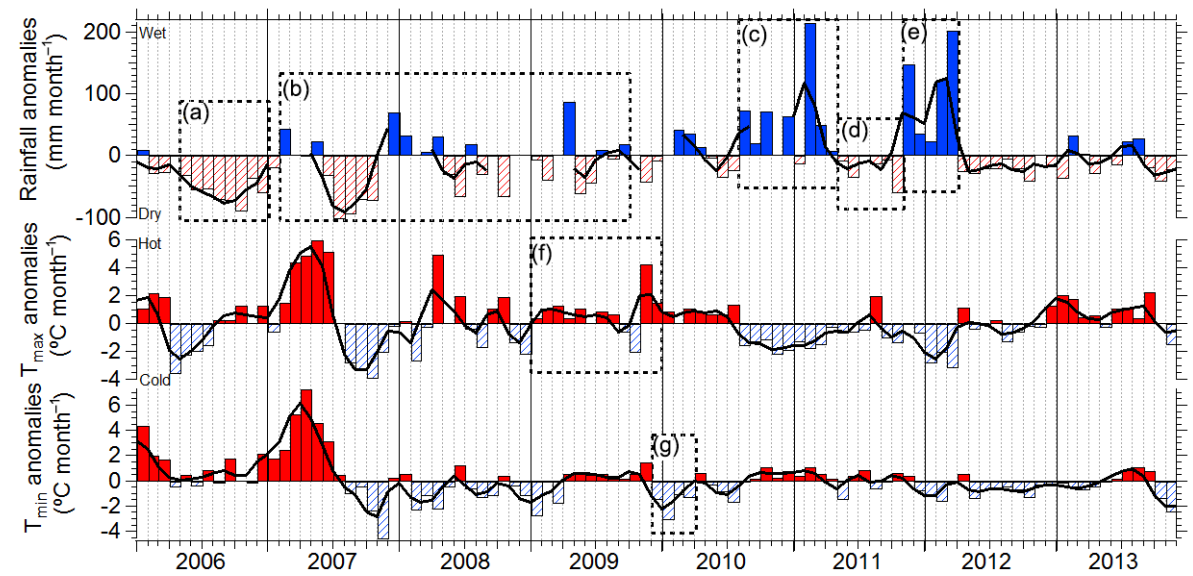

Figure 3. Monthly rainfall, minimum temperature $\left(T_{\min }\right)$ and maximum temperature $\left(T_{\max }\right)$ anomalies at Yarrangobilly Caves (BoM station 72141) during the cave drip-water monitoring study period. The solid line is the result of applying a binomial smoothing, one-pass Gaussian filter to the monthly data. 


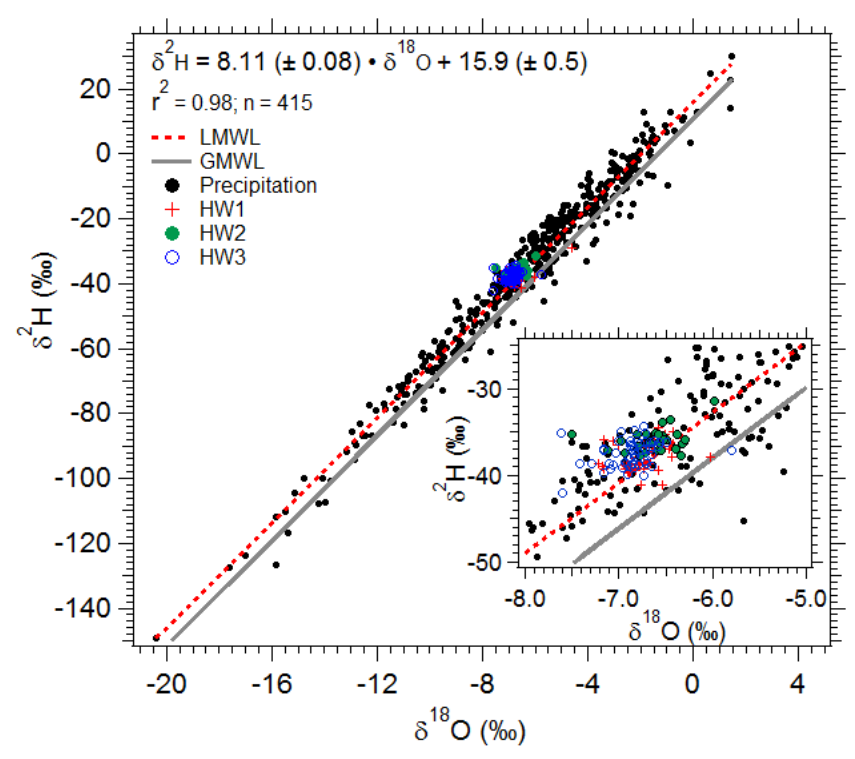

Figure 4. Linear fit representing the LMWL for the relationship between $\delta^{2} \mathrm{H}$ and $\delta^{18} \mathrm{O}$ in daily precipitation samples (dashed red line) and cave drip water (HW1-3). The solid grey line denotes the position of the GMWL.

pared to rainfall. Site HW2 had a wider range of $\delta^{18} \mathrm{O}$ values $(-5.4--7.7 \%$ ) than site HW1 $(-6.0--7.4 \%$ ) and HW3 $(-5.7--7.9 \%)$. The $\delta^{18} \mathrm{O}$ arithmetic mean values, close to the PWM $(-6.9 \%)$, were $-6.8 \pm 0.3 \%$ for HW1 and 2 and $-6.9 \pm 0.3 \%$ o for HW3, suggesting significant mixing of infiltration events and that evaporation of infiltrating water is not significant. There is no clear seasonality in drip-water $\delta^{18} \mathrm{O}$, in contrast to the rainfall $\delta^{18} \mathrm{O}$, and there appears to be no simple isotopic response to infiltration of winter rainfall (Fig. 2). Furthermore, at all sites the mean drip-water $\delta^{18} \mathrm{O}$ values are similar prior to mid-2010 during the dry period compared to the wettest interval between mid-2010 and March 2011 (HW1: $-6.7 \%$ cf. $-7.0 \%$; HW2: $-6.6 \%$ cf. $-6.9 \%$; and HW3: $-6.9 \%$ of. $-6.9 \%$ ), although there is a subtle trend to lighter $\delta^{18} \mathrm{O}$ values.

Figure 4 shows $\delta^{2} \mathrm{H}$ vs. $\delta^{18} \mathrm{O}$ calculated local meteoric water line (LMWL; $\delta^{2} \mathrm{H}=(8.11 \pm 0.08) \times \delta^{18} \mathrm{O}+(15.9 \pm 0.5)$, $n=415)$ compared with the global meteoric water line (GMWL; Rozanski et al., 1993). The LMWL intercept is greater than the GMWL, but is in agreement with the LMWL established by Hughes and Crawford (2013) from a 3-year precipitation dataset from Big Hill in the Southern Highlands $\left(\delta D=(8.10 \pm 0.12) \times \delta^{18} \mathrm{O}+(16.3 \pm 0.8) ; 188 \mathrm{~km}\right.$ northeast (NE) of our site, $652 \mathrm{~m}$ a.s.l.). Crawford et al. (2013) attributed the high intercept value to a larger contribution of moisture recycling from the land surface to the local moisture budget.

\subsection{Drip rates}

Drip rates throughout the 7-year period demonstrate irregular multi-annual variations (Fig. 2d). All sites remained hydrologically active, with a mean drip rate of $2.2 \pm 0.6, \quad 2.2 \pm 1.7$ and $3.5 \pm 1.9 \times 10^{-3} \mathrm{~mL} \mathrm{~s}^{-1}$ at site HW1-3 respectively (Table 3). Prior to mid2010 , during the long phase of below average monthly rainfall and water deficit, a base-flow drip rate of $2.1 \pm 0.5 \times 10^{-3} \mathrm{~mL} \mathrm{~s}^{-1}$ for HW1, $1.9 \pm 1.4 \times 10^{-3} \mathrm{~mL} \mathrm{~s}^{-1}$ for HW2 and $3.1 \pm 1.3 \times 10^{-3} \mathrm{~mL} \mathrm{~s}^{-1}$ for HW3 was maintained, only increasing slightly in response to above-average monthly rainfall anomalies during this period (Sect. 4.2), therefore suggesting the drip sites receive flow from a storage reservoir. The increased rise in discharge is often only captured by one fortnightly sampling event, but is often present at all three sites. During the wettest interval between mid-2010 and March 2011, the mean drip rate increased to between 2.8 and $4.7 \times 10^{-3} \mathrm{~mL} \mathrm{~s}^{-1}$ (Fig. $2 \mathrm{~d}$ ). Site HW2 is a slower dripping site compared to HW1, and HW3 is the fastest dripping stalactite. Drip rates at all three sites are mostly in phase, recording a similar pattern.

\subsection{Drip-water chemistry}

Concentrations of major cations and anions in the drip-water samples from the three drip sites are listed in Table 3. Dripwater samples from all three sites represent a $\mathrm{Ca}-\mathrm{HCO}_{3}$ dominating water type (pH 6.8-8.3) (Drever, 1982); accordingly, $\mathrm{Ca}$ is the main cation in the drip-water solutions. The mean $\mathrm{Ca}$ concentrations observed at drip sites HW1-3 are $66.4,56.4$ and $63.0 \mathrm{mg} \mathrm{L}^{-1}$ respectively, and range from 31.1 to $84.1 \mathrm{mg} \mathrm{L}^{-1}$. Mean concentrations of other ions are similar across the three drip sites, further supporting that the drip water is sourced from the same well-mixed storage reservoir.

Time series of $\mathrm{Ca}, \mathrm{Mg} / \mathrm{Ca}, \mathrm{Sr} / \mathrm{Ca}$ and $\mathrm{Cl}$ are shown in Fig. 2. Broadly, $\mathrm{Ca}$ concentrations are declining from 80 to $60 \mathrm{mg} \mathrm{L}^{-1}$ at sites HW1 and 3 from the beginning of the study until early 2008 when they become more similar to one another, but still greater than HW2 (which remains lower at $50 \mathrm{mg} \mathrm{L}^{-1}$ through the same period). There is a prominent rise in $\mathrm{Ca}$ at all sites beginning in the summer of 2008/2009 and peaking in November 2009 at ca. $80 \mathrm{mg} \mathrm{L}^{-1}$, before falling back to ca. $60 \mathrm{mg} \mathrm{L}^{-1}$ in autumn 2010. After this time, and throughout the following wetter interval, Ca concentrations at all sites become closer in value and less variable overall with some excursions to lower $\mathrm{Ca}$ at individual drip sites over periods of $0.5-2$ months.

The prominent Ca peak in 2009 also occurs during a dry period when $\mathrm{Ca}$ is increasing rather than decreasing. In this case, this prominent peak in $\mathrm{Ca}$ occurs during a persistent run of above-average surface temperatures dominating the entire year (Fig. 3). Specifically, an unusually warm winter was experienced in 2009 (Fig. 3f), followed by the hottest November on record (BoM; 2015b). We propose that, in this 
Table 3. Summary statistics of dominant ions in fortnightly drip-water samples analysed between 2006 and 2013.

\begin{tabular}{|c|c|c|c|}
\hline & HW1 mean \pm SD $(\min , \max )$ & HW2 mean \pm SD $(\min , \max )$ & HW3 mean $\pm \mathrm{SD}(\min , \max )$ \\
\hline Drip rate $\left(\times 10^{-3} \mathrm{~mL} \mathrm{~s}^{-1}\right)$ & $2.2 \pm 0.6(0.8,4.8)$ & $2.2 \pm 1.7(0.2,15)$ & $3.5 \pm 1.9(0.06,13.6)$ \\
\hline$T\left({ }^{\circ} \mathrm{C}\right)$ & $11.1 \pm 0.4(10.4,11.9)$ & $11.1 \pm 0.4(10.4,11.8)$ & $11.0 \pm 0.4(10.3,11.8)$ \\
\hline $\mathrm{EC}\left(\mu \mathrm{S} \mathrm{cm}^{-1}\right)$ & $311 \pm 16(275,356)$ & $272 \pm 33(161,330)$ & $293 \pm 30(199,333)$ \\
\hline $\mathrm{pH}$ & $7.82 \pm 0.53(7.17,11.20)$ & $7.86 \pm 0.45(7.37,11.00)$ & $7.79 \pm 0.43(7.32,11.00)$ \\
\hline \multicolumn{4}{|l|}{ Cation } \\
\hline $\mathrm{Ca}\left(\mathrm{mg} \mathrm{L}^{-1}\right)$ & $66.4 \pm 5.5(55.7,84.1)$ & $56.5 \pm 7.8(31.1,81.4)$ & $63.0 \pm 7.2(41.5,80.6)$ \\
\hline $\mathrm{Si}\left(\mathrm{mg} \mathrm{L}^{-1}\right)$ & $2.3 \pm 0.6(1.4,3.5)$ & $2.3 \pm 0.6(1.4,3.8)$ & $2.3 \pm 0.6(1.3,3.5)$ \\
\hline$* \mathrm{Na}\left(\mathrm{mg} \mathrm{L}^{-1}\right)$ & $0.7 \pm 0.04(0.6,0.8)$ & $0.7 \pm 0.1(0.6,0.9)$ & $0.7 \pm 0.2(0.6,0.8)$ \\
\hline $\operatorname{Mg}\left(\mathrm{mg} \mathrm{L}^{-1}\right)$ & $0.58 \pm 0.05(0.44,0.68)$ & $0.58 \pm 0.05(0.45,0.73)$ & $0.58 \pm 0.05(0.45,0.82)$ \\
\hline $\mathrm{K}\left(\mathrm{mg} \mathrm{L}^{-1}\right)$ & $0.12 \pm 0.04(0.07,0.32)$ & $0.13 \pm 0.05(0.08,0.35)$ & $0.11 \pm 0.04(0.06,0.32)$ \\
\hline $\operatorname{Sr}\left(\mu \mathrm{gL}^{-1}\right)$ & $51.8 \pm 6.7(31.6,61.0)$ & $51.0 \pm 6.3(32.3,64.0)$ & $51.3 \pm 6.4(31.9,76.0)$ \\
\hline \multicolumn{4}{|l|}{ Anion } \\
\hline $\mathrm{Cl}\left(\mathrm{mg} \mathrm{L}^{-1}\right)$ & $1.5 \pm 0.4(1.0,2.7)$ & $1.6 \pm 0.4(1.1,2.5)$ & $1.6 \pm 0.4(1.0,3.0)$ \\
\hline $\mathrm{SO}_{4}\left(\mathrm{mg} \mathrm{L}^{-1}\right)$ & $0.6 \pm 0.3(0.2,1.3)$ & $0.6 \pm 0.2(0.2,1.1)$ & $0.6 \pm 0.2(0.2,1.1)$ \\
\hline \multicolumn{4}{|l|}{ Elemental ratio } \\
\hline $\mathrm{Mg} / \mathrm{Ca}\left(\mathrm{mmol} \mathrm{mol}^{-1}\right)$ & $14.3 \pm 1.3(10.5,17.1)$ & $17.1 \pm 2.1(13.1,30.1)$ & $15.3 \pm 2.0(10.7,23.8)$ \\
\hline $\mathrm{Sr} / \mathrm{Ca}\left(\mathrm{mmol} \mathrm{mol}^{-1}\right)$ & $0.36 \pm 0.05(0.21,0.44)$ & $0.42 \pm 0.1(0.26,0.71)$ & $0.06(0.21,0.57)$ \\
\hline
\end{tabular}

${ }^{*} n=68$ samples from 15 March 2011 to 23 December 2013.

interval, higher than average drip-water $\mathrm{Ca}$ concentrations are driven by a temperature control on net soil $\mathrm{CO}_{2}$ due to respiration. We therefore propose that the warmer than average temperatures, particularly during the winter months, induced higher soil $\mathrm{CO}_{2}$ respiration and thereby increasing $\mathrm{CaCO}_{3}$ dissolution. Drip-water Ca returned to mean levels in January 2010 (Fig. 2f), consistent with cooler temperatures (minimum temperatures were $3.1^{\circ} \mathrm{C}$ lower than the longterm average) restoring soil respiration conditions to previous levels (Fig. 3g).

Chloride concentrations show consistent trends through time across the three sites. Chloride concentrations are the highest at the beginning of our study (ca. $2.3 \mathrm{mg} \mathrm{L}^{-1}$ ) and decline steadily until mid-2010; at which time there is a more abrupt decrease in mean $\mathrm{Cl}$ at all three sites. After this transition, $\mathrm{Cl}$ concentrations are relatively stable at ca. $1.3 \mathrm{mg} \mathrm{L}^{-1}$. Chloride is our most conservative of the measured ions. During the transition from the relatively drier to the relatively wetter interval in our study, the abrupt decline in $\mathrm{Cl}$, coinciding with an increase in discharge is consistent with dilution by recharge at the onset of the wetter interval (Fig. 2i). The earlier downward trend in $\mathrm{Cl}$ (2007-mid-2010) appears initially inconsistent with this, but we propose that reduced recharge events to the epikarst storage reservoir during this interval resulted in a decreasing supply of $\mathrm{Cl}$ from the soil zone (discussed further in Sect. 5.1).

\subsection{Drip-water mixing and PCP evolution}

The observations above suggest processes include the mixing and dilution of drip water as indicated by $\mathrm{Cl}$ concentrations. To diagnose water-rock interactions including PCP and mixing of waters, we used a number of approaches (Sect. 3.3). Figure 5 shows a cross-plot of $\ln (\mathrm{Mg} / \mathrm{Ca})$ vs. $\ln (\mathrm{Sr} / \mathrm{Ca})$ drip-water ratios presented together with the bedrock $\ln (\mathrm{Mg} / \mathrm{Ca})$ and $\ln (\mathrm{Sr} / \mathrm{Ca})$ ratios (after Sinclair et al., 2012, and Tremaine and Froelich., 2013). Since all three drip sites are influenced by the same processes, as the same $\mathrm{Mg}(\mathrm{Sr}) / \mathrm{Ca}$ trends are observed at all sites (Supplement S3), we present drip-water data at site HW2 for visual clarity as the processes are enhanced due to the slower discharge at this site. Many of the bedrock values are similar but lower than the drip-water $\ln (\mathrm{Mg} / \mathrm{Ca})$ and $\ln (\mathrm{Sr} / \mathrm{Ca})$ ratios (Fig. 5). The drip-water data themselves appear to fall into two groups: the pre-October 2007 group (red squares) with relatively lower $\mathrm{Sr} / \mathrm{Ca}$ ratios, and the post-November 2007 group with relatively higher $\mathrm{Sr} / \mathrm{Ca}$ ratios. If the geochemical evolution of the drip water was solely due to PCP, Sinclair et al. (2012) mathematically demonstrated that the drip-water ratios would produce a straight-line correlation of known slope through the whole dataset (Sect. 3.3). The observed step change indicates a change in the initial composition of the chemistry at equilibration. We interpret this to indicate a flow path change, which we discuss further in 


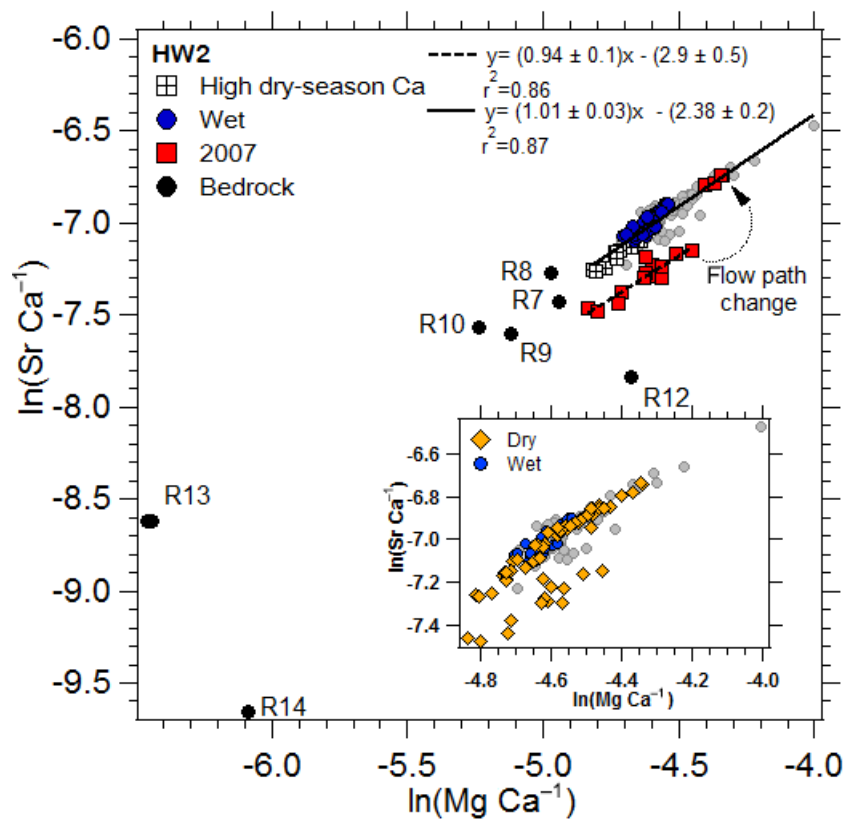

Figure 5. Drip-water $\ln (\mathrm{Sr} / \mathrm{Ca})$ vs. $\ln (\mathrm{Mg} / \mathrm{Ca})$ ratios at site HW2 are graphed together with the bedrock composition (see Table 2). To enhance clarity, high dry-season $\mathrm{Ca}$, wet and 2007 drip-water chemistry trends are discriminated from the complete dataset (light grey circles). The step change, offsetting between the two linear trends, is indicated by a curved arrow. Inset highlights dry and wet period data.

Sect. 5.1. All HW2 drip-water values are consistent with evolution from the bedrock values, notably R7 to R10.

Linear regressions are plotted for each group of data in Fig. 5. There is some scatter of the data around these lines suggesting that more than one process may be influencing the resulting drip-water $\mathrm{Sr} / \mathrm{Ca}$ and $\mathrm{Mg} / \mathrm{Ca}$ ratios. During low discharge and dry rainfall conditions the drip-water composition shifts to higher $\mathrm{Mg} / \mathrm{Ca}$ and $\mathrm{Sr} / \mathrm{Ca}$ ratios away from the bedrock plotting in the distal outer ends, representing progressive $\mathrm{CO}_{2}$ degassing due to increased PCP. During the transition period from dry to wet conditions in mid-2010 when discharge increased (blue filled circles in Fig. 5), dripwater $\mathrm{Mg} / \mathrm{Ca}$ and $\mathrm{Sr} / \mathrm{Ca}$ ratios plot closer to the bedrock region, indicating reduced PCP. During the high dry-season $\mathrm{Ca}$ values (November 2009, square window), $\mathrm{Mg}(\mathrm{Sr}) / \mathrm{Ca}$ ratios are close to the bedrock ratios. As drip water reached maximum $\mathrm{Ca}$ values, $\mathrm{Mg}(\mathrm{Sr}) / \mathrm{Ca}$ ratios evolved towards slightly lower values, due to dissolution of the host limestone, caused by increased soil $\mathrm{CO}_{2}$ from bioproductivity. An alternative hypothesis for the rise in $\mathrm{Ca}$ in late 2009 could be a flow path change; however, the $\mathrm{Sr} / \mathrm{Ca}$ and $\mathrm{Mg} / \mathrm{Ca}$ data show no evidence to support this.

The calculated drip-water $\ln (\mathrm{Sr} / \mathrm{Ca})$ vs. $\ln (\mathrm{Mg} / \mathrm{Ca})$ (weight ratio) correlation slopes of the two groups of data at each drip site range between $0.66 \pm 0.17$ and $1.01 \pm 0.07$, within the range of predicted slopes suggested by Sinclair et al. (2012). Although a slight slope change is observed between the two flow paths, this suggests that cave drip water evolves under PCP.

Unlike the late 2007 step change, we observe a rise in $\mathrm{Mg}(\mathrm{Sr}) / \mathrm{Ca}$ and a drop in $\mathrm{Ca}$ in 2011 and 2013 (arrows; Fig. 2). These events are short-lived and are most notable at one site only (HW2); there is insufficient data to evaluate this site-specific change and nonetheless are features that would not be preserved in the speleothem.

Excluding 2007, the long-term $\mathrm{Mg}$ values are increasing relative to $\mathrm{Ca}$ and there is a drift towards higher $\mathrm{Mg} / \mathrm{Ca}$ values overall but less evident in the $\mathrm{Sr} / \mathrm{Ca}$ time series (Fig. 2). There is a long-term rise in $\mathrm{Mg}$ concentrations of $0.15 \mathrm{ppm}$ from 2008 to 2013. A more complete characterization will include an investigation of aerosols and soil in a future study.

\section{Discussion}

Speleothem geochemical proxy records archive environmental and climate signals from the surface to the cave (Fairchild and Treble, 2009). However, informed palaeorainfall reconstruction from speleothems requires an understanding of the drip hydrological pathway and the karst hydrogeological influences, preferably based on modern cave monitoring data from similar climates. In this section we discuss the key results used to constrain the hydrological processes that characterize drip sites HW1-3 based on discharge, geochemical and stable isotope parameters in contrasting rainfall conditions, highlighting the importance of constraining the evolution of the drip water in the context of the local environment. Multiple lines of evidence indicate the drip sites are constrained by multiple processes, which we summarize in a conceptual model. We examine the relationship between the observed hydrogeochemical changes with the climate. Our findings underlie the use of geochemical tracers toward informing speleothem proxy records and we also discuss the implications of these results for palaeoenvironmental reconstruction.

\subsection{Hydrogeochemical processes influencing drip-water chemistry}

Based on hydrogeochemical observations presented in Sect. 4, we suggest in Harrie Wood Cave the flow paths feeding stalagmites from drip sites HW1-3 are from a Type 1, mixed-flow/storage connectivity low-flow sub-type, i.e. fracture flow from a "pocket reservoir" in the wellmixed epikarst storage reservoir (Markowska et al., 2015; see Sect. 2.2). Our data confirm the drip water that precipitates speleothem calcite drains from bulk homogenized epikarst store water, the primary karst storage reservoir at Harrie Wood Cave. The results from the oxygen-isotope data indicate that infiltrating water is well-mixed, because the range of 
drip-water $\delta^{18} \mathrm{O}$ values is narrow in comparison to the rainfall, and the arithmetic mean of the drip water reflects the weighted mean of precipitation (Sect. 4.3); moreover, from the drip-water isotope time series there is a strong buffering of the extremely low $\delta^{18} \mathrm{O}$ winter rainfall values in 2007, 2010, 2012 and 2013 (Fig. 2). Furthermore, consistency in trace element trends among the sites (Table 3) confirms the karst waters are well homogenized.

A significant proportion of flow to the drip points is drained from a storage reservoir, owing to sustained baseflow discharge levels during the weak El Niño in 2006 and the low rainfall period between 2007 and 2009 (Sect. 4.4). Furthermore, as base flow is maintained and a large infiltration event or threshold level is not required to activate the drip site; this suggests the karst plumbing system feeding the stalagmites is not as described by Markowska et al. (2015), i.e. a Type 2 extreme event activated or Type 3 overflow site (see Sect. 2.2).

Dilution of the epikarst storage reservoir was observed during the transition to the La Niña phase in 2010/2011, consistent with the observation of a clear increase in discharge followed by a decrease in $\mathrm{Cl}$ concentrations. This further suggests that after recharge the epikarst storage reservoir volume reached close to maximum capacity maintaining "steady state", supported by the drip-water $\mathrm{Mg} / \mathrm{Ca}$ and $\mathrm{Sr} / \mathrm{Ca}$ ratios reaching mean levels indicating minimum PCP. Additionally, this indicates that discharge at the drip sites are not from a Type 1 (high flow sub-type), Type 4 or Type 5 site, as during periods of water excess discharge at these sites receive flow directly from the soil storage reservoir, and therefore a rise in $\mathrm{Cl}$ would be anticipated due to higher ET to the system as a whole; however, the converse was observed.

During the dry period from 2007 to mid-2010, we suggest the decreasing trend from elevated $\mathrm{Cl}$ levels indicates limited recharge. During the dry period we observe a decline in the CWB and reduced drip rate, consistent with fewer recharge events from the soil-vadose zone to the epikarst store, and therefore decreasing drip-water $\mathrm{Cl}$ concentrations. Alternatively, it may also reflect higher ET in the soil-vadose zone, but this would also result in an enriched drip-water $\delta^{18} \mathrm{O}$ signal. ET is relevant at this karst site; however, we do not favour this explanation, as the similarity between drip-water $\delta^{18} \mathrm{O}$ values during the dry period compared to the wetter period suggests evaporation of the infiltrating drip water was not significant (Sect. 4.3).

A flow path change at October 2007 is inferred from the shift to higher $\mathrm{Sr} / \mathrm{Ca}$ ratios (Sect. 4.6; Fig. 5). This process occurred during the drying conditions when the CWB was decreasing (Fig. 2b), but when base-flow levels were maintained at all drip sites during this period. We infer that a flow path re-direction through a higher $\mathrm{Sr} / \mathrm{Ca}$ endmember occurred due to soil-vadose zone drying to sustain discharge. This indicates a non-linear response of the system to progressive drying. A possible explanation is that calcification of the flow path produced a threshold change causing re-routing through a higher $\mathrm{Sr} / \mathrm{Ca}$ source.

The three drip-water monitoring sites (HW1-3) are located within a small area (Fig. 1b); however, there are differences in the chemistry, which is notable in 2007 during the earliest interval of the dry period. In particular a lower drip rate (Sect. 4.4) and a lower Ca concentration and higher $\mathrm{Mg} / \mathrm{Ca}$ and $\mathrm{Sr} / \mathrm{Ca}$ ratio (Sect. 4.5) of site HW2 compared to the neighbouring sites HW3 and 1, which are only 10$15 \mathrm{~cm}$ away. Equivalent $\mathrm{Cl}$ concentrations over this period (Sect. 4.5) suggest differences have subsequently arisen in the carbonate chemistry. A potential explanation for this is that all three drip sites are fed by the same chemistry, but the lower drip rate at site HW2 is consistent with greater in-cave PCP on the stalactite tip, inducing a lower $\mathrm{Ca}$ concentration and enhancing PCP (Treble et al., 2015).

Thus, we deduce that the studied drip water is from a Type 1 mixed-flow/storage connectivity low-flow sub-type, the system is open to $\mathrm{CO}_{2}$, and a ventilated air pocket with variable height and lower $p \mathrm{CO}_{2}$ provides the potential for degassing and calcite precipitation from the drip water (Tooth and Fairchild, 2003). Although we observed a hydrological flow path change, a distinction in drip-water $\mathrm{Mg} / \mathrm{Ca}$ and $\mathrm{Sr} / \mathrm{Ca}$ composition between drier and wetter periods is evident. During dry periods, the PCP mechanism was enhanced and the highest $\mathrm{Mg} / \mathrm{Ca}$ and $\mathrm{Sr} / \mathrm{Ca}$ ratios in this study are recorded during the El Niño and intervals of below average rainfall, as PCP is promoted due to a dewatering of spaces. In contrast, for the duration of the strong La Niña phase in 2010/11 and above-average rainfall, reduced PCP (mean $\mathrm{Mg} / \mathrm{Ca}$ and $\mathrm{Sr} / \mathrm{Ca}$ ratios) is noted (blue circles, Fig. 5) since a reduced reservoir head space limits degassing.

We also examine the role of calcite dissolution and soil zone $\mathrm{CO}_{2}$ in more detail. Drip-water $\mathrm{Ca}$ concentrations reached maximum values $\left(80 \mathrm{mg} \mathrm{L}^{-1}\right)$ in November 2009 (see Fig. 2f), as unseasonal temperatures increased. We suggest that soil microbial production increased the $\mathrm{CO}_{2}$ concentration of infiltrating waters driving $\mathrm{CaCO}_{3}$ mineral dissolution (square window, Fig. 5). Presumably vadose zone $\mathrm{CO}_{2}$ production also drives calcite dissolution during the dry period (Atkinson et al., 1977). During the dry period there is a long-term decline in the CWB and progressive draining of the epikarst store; therefore, more unsaturated zone is available for $\mathrm{CO}_{2}$ production, which may also lead to increased calcite solubility.

An alternative hypothesis is the $\mathrm{Ca}$ trend may be a firedriven process as the site was affected by fire 4 years before the monitoring period, which may have decreased soil $\mathrm{CO}_{2}$ production, associated calcite dissolution and $\mathrm{Ca}$ concentrations (Coleborn et al., 2006). That effect is most likely in the first decade after the fire. However, a decreasing trend in $\mathrm{Ca}$ in the early monitoring period (the opposite of what might be expected) in combination with thin soil and sparse vegetation indicates that any fire-induced soil biogeochemical changes had relatively little impact on the drip-water signa- 


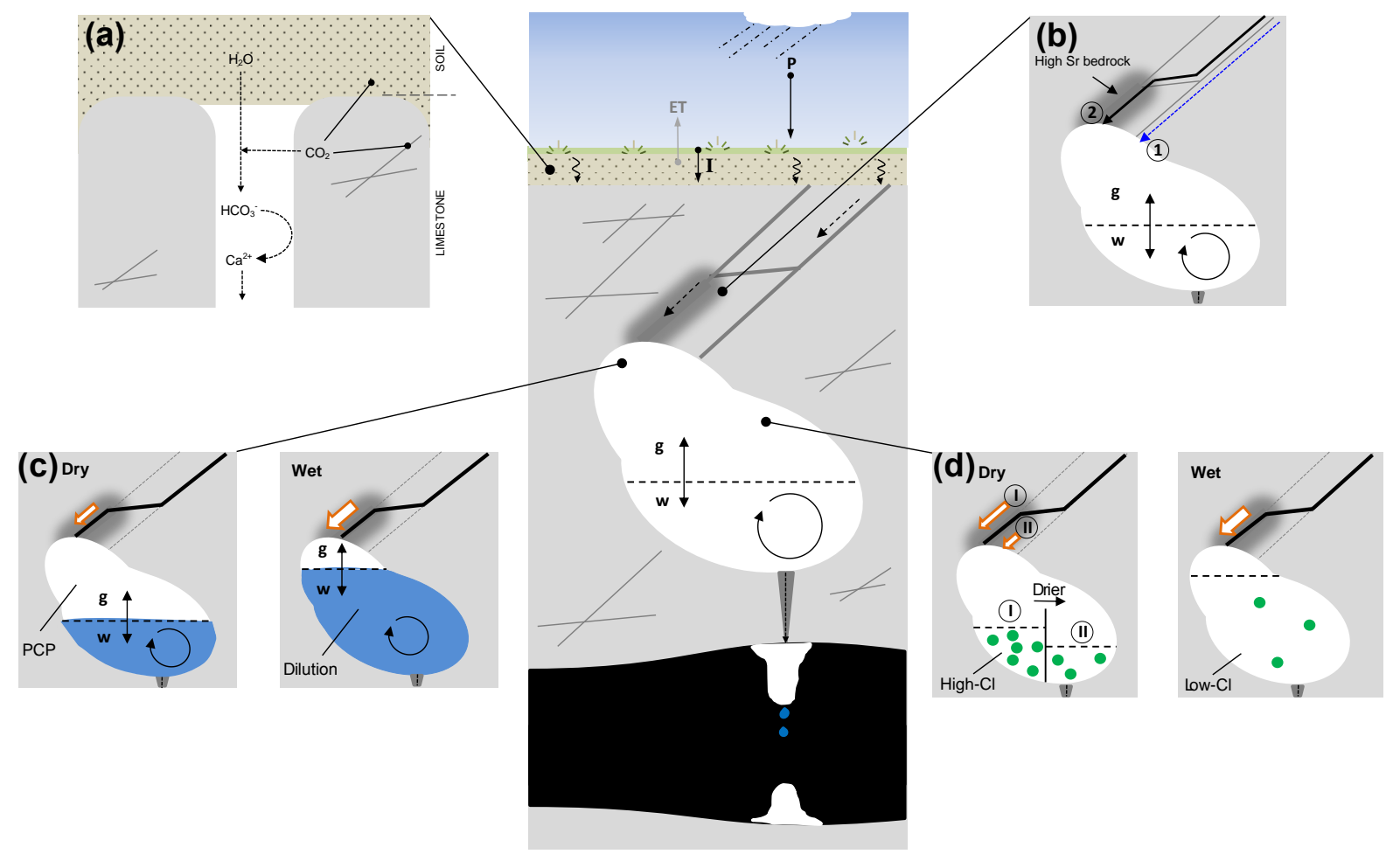

Figure 6. Conceptual model summarizing key process affecting drip-water hydrochemical variations at Harrie Wood Cave. Shown are precipitation $(P)$, evapotranspiration $(E T)$ and infiltration $(I)$ infiltrations corresponding to when rainfall exceeds $13 \mathrm{~mm}$. Stalactites from drip sites HW1-3 are fed by fracture flow from a ventilated well-mixed pocket reservoir with a variable head within the epikarst. (a) Soil and unsaturated/vadose zone $\mathrm{CO}_{2}$ drive $\mathrm{CaCO}_{3}$ dissolution, increasing drip-water $\mathrm{Ca}$. (b) The host bedrock varies geochemically and the dark grey shading along the fracture represents bedrock of higher Sr concentrations. A flow path change from 1 to 2 (October 2007) results in drip water being enriched in Sr. The size of flow arrows in (c) and (d) qualitatively correspond to recharge to the epikarst storage reservoir. (c) PCP within the store is enhanced during dry periods as the water level $(w)$ is low, fairly constant and in contact with a greater ventilated gas phase $(g)$. Dilution occurs during wet intervals due to greater inflow and PCP decreases as a reduced reservoir head space limits degassing $(w>g)$. (d) During dry periods, the response to reduced inflow (I to II) is a decrease in Cl concentrations within the storage reservoir and therefore drip water. In wet periods, $\mathrm{Cl}$ is flushed from the soil-vadose zone and then diluted within the store, resulting in a sharp decline in drip-water $\mathrm{Cl}$.

ture. Also, in the short term, the concentration of elements in the soil can increase in response to a fire. Considering this, during the drying trend when there is reduced recharge and based on the observed trend of the conservative tracer $\mathrm{Cl}$, the effect would be an analogous decrease in $\mathrm{Mg}$ and $\mathrm{Sr}$ concentrations in the drip water, whereas a long-term rise in $\mathrm{Mg}$ is noted (Sect. 4.6), as such we do not consider the 2003 fire event had an impact on the drip-water dataset.

Based on a 7-year observational study, we have unveiled a complex non-linear geochemical response, as depicted in Fig. 6. We now attempt to discern whether these long-term trends in the geochemistry are climate related. During the drying trend (2007 to mid-2010), we observed low discharge, a flow path change, decreased $\mathrm{Cl}$, enhanced and increased $\mathrm{Ca}$ caused by increased $\mathrm{CaCO}_{3}$ solubility due to higher soil $\mathrm{CO}_{2}$ and bioproductivity. This is a response consistent with reducing recharge conditions. During the wetter period, we also observed trends consistent with increased recharge, in- creased discharge, dilution and reduced PCP. Therefore, we interpret these as evidence of climatic induced changes. Over the long-term, drip discharge and hydrogeochemical variations between the relatively dry and wet period are driven by variations in water availability due to ENSO and are of palaeoclimatic relevance.

We have confidently constrained the possible hydrological processes, which can occur in a karst system situated in a region greatly impacted by ENSO episodes. We attribute this to long-term monitoring that encapsulated the shift between the two extremes of ENSO, namely from dry El Niño to wet La Niña conditions. Based on our findings and with the knowledge that the impact of each ENSO episode on Australia varies, we have identified how Harrie Wood Cave responds to a changing climate signal (rainfall), and through geochemical proxies $\left(\delta^{18} \mathrm{O}, \mathrm{Ca}, \mathrm{Cl}\right.$, and $\mathrm{Mg} / \mathrm{Ca}$ and $\mathrm{Sr} / \mathrm{Ca}$ ratios) identified how this response has been transformed and is recorded in cave drip water over time. These results 
have important implications in informing palaeoclimate findings from speleothem archives, which we discuss further in Sect. 5.2.

\subsection{Implications for speleothems as palaeorainfall recorders}

Our results provide a foundation to inform speleothem palaeoclimate records where drip-water compositions are influenced by multiple processes. During our studied interval, element concentrations and ratios in the drip water were driven by climate (ENSO) and karst hydrological processes. Based on drip characterization of sites $\mathrm{HW} 1-3, \mathrm{Mg} / \mathrm{Ca}$ variations in the conjugate stalagmite could in principle, be successfully applied to construct palaeorainfall conditions (Tooth and Fairchild, 2003; Markowska et al., 2015). We have demonstrated that drip-water $\mathrm{Mg} / \mathrm{Ca}$ and $\mathrm{Sr} / \mathrm{Ca}$ ratios are a relative measure of modern rainfall variability. Therefore, in a highly resolved speleothem time series, we anticipate displacements of $[\mathrm{Mg} / \mathrm{Ca}]_{\text {calcite }}$ and $[\mathrm{Sr} / \mathrm{Ca}]_{\text {calcite }}$ from a baseline ratio (bedrock) to higher and mean ratios will differentiate between dry and wet periods respectively. McDonald et al. (2004) also identified a relationship between drip-water $\mathrm{Mg} / \mathrm{Ca}$ and $\mathrm{Sr} / \mathrm{Ca}$ ratios and drought in Wombeyan Caves, New South Wales (NSW); however, their interpretation of the trace element stalagmite record varies slightly. At Wombeyan, PCP is a more dominant control on the karst hydrochemistry, although it is in the same climate region, but a warmer site with greater evapotranspiration and a longer growing season. Consequently, we would expect that the resultant drip water (and stalagmite calcite) would be enriched in $\mathrm{Mg} / \mathrm{Ca}$ and $\mathrm{Sr} / \mathrm{Ca}$. As such we expect to observe a greater displacement of $\mathrm{Mg} / \mathrm{Ca}$ ratios away from the bedrock composition during any given dry phase at Wombeyan Caves, in comparison to a corresponding record at Harrie Wood Cave. For wet periods, no La Niña events occurred during their study period (July 2001January 2004); therefore, McDonald et al. (2004) could only speculate $\mathrm{Mg}$ / Ca calcite ratios would shift towards bedrock values due to a decreased effect of PCP. In contrast, extended monitoring through the La Niña mode of an ENSO cycle provides us with a more informed interpretation; whereby we anticipate La Niña events in the stalagmite trace element time series may be resolved from baseline ratios by a shift to mean ratios.

\section{Conclusions}

This research targeted the Snowy Mountains region of the Australian Alps; a key water resource region in SE Australia where rainfall variability and, therefore, future water resource availability in this climatically sensitive region is uncertain. Our results have advanced the scientific knowledge of the in-cave drip response to modern-ENSO variabil- ity, via rainfall, and therefore enabled the identification of the most reliable geochemical proxies (trace element concentrations and $\delta^{18} \mathrm{O}$ ) for palaeoclimate reconstruction from speleothem archives within Harrie Wood Cave and in the region.

This study underpins the importance of extended monitoring through a modern ENSO cycle and we document a site where a number of concurrent hydrological processes are occurring, occasioning a complex non-linear geochemical dripwater signature. The local karst hydrogeological processes, which influence trace element and $\delta^{18} \mathrm{O}$ proxies in drip water, and therefore signatures in the speleothem calcite, were constrained. We identified discharge at drip sites HW1-3 is from a well-mixed pocket reservoir in the epikarst storage reservoir.

Interpretation of drip-water $\mathrm{Ca}, \mathrm{Cl}, \mathrm{Mg} / \mathrm{Ca}$ and $\mathrm{Sr} / \mathrm{Ca}$ ratios during contrasting rainfall conditions allowed the following processes to be constrained. During the El Niño and dry periods, enhanced PCP resulted in higher $\mathrm{Mg} / \mathrm{Ca}$ and $\mathrm{Sr} / \mathrm{Ca}$ ratios. While during the La Niña and wet phase, $\mathrm{Cl}$ concentrations and discharge were used to constrain the process of dilution and reduced PCP controlled drip chemistry. However, we found a number of non-linear responses embedded in a linear drying climate trend. An interpretation of drip-water $\mathrm{Sr} / \mathrm{Ca}$ vs. $\mathrm{Mg} / \mathrm{Ca}$ ratios compared to different endmember bedrock ratios showed a shift to higher $\mathrm{Sr}$ values, suggesting a flow-path change. Decreasing drip-water $\mathrm{Cl}$ levels indicated reduced recharge of the epikarst storage reservoir, and an unexpected rise in the $\mathrm{Ca}$ time series was shown to be caused by carbonate dissolution due to an increase in soil and epikarst-vadose zone $\mathrm{CO}_{2}$ concentrations. The data presented here highlight the complex interplay of a drip-water signal in response to the climate signal, this has been achieved only through long-term monitoring over a 7-year (2007-2013) period. A conceptual model was constructed illustrating these key processes controlling the dripwater composition.

These processes are shown to be linked to climate induced changes and propose $\mathrm{Mg} / \mathrm{Ca}$ and $\mathrm{Sr} / \mathrm{Ca}$ variations in the conjugate stalagmite could, in principle, be successfully applied to construct palaeorainfall conditions. This study has extended our understanding of changing climatic controls on proxy variations within the Harrie Wood Cave system and, therefore, provides a benchmark for its application regionally and globally when using speleothems for palaeoclimate reconstruction.

\section{Data availability}

Time series of rainfall and drip-water data used in this study are available upon request from the corresponding author. The Southern Oscillation Index monthly data are publicly available (http://www.bom.gov.au/climate/current/ soihtm1.shtml). This work used data acquired from the Aus- 
tralian Water Availability Project (AWAP), AWAP model results can be accessed by contacting Peter Briggs (http: //www.csiro.au/awap/; peter.briggs@csiro.au).

\section{The Supplement related to this article is available online at doi:10.5194/hess-20-4625-2016-supplement.}

Author contributions. Carol V. Tadros conceptualized the research, collected data, conducted all data analysis and interpretation, generated graphs, the conceptual model and wrote the manuscript. Pauline C. Treble and Andy Bake provided guidance, reviewed and edited the manuscript in their function as my supervisors, as did Ian Fairchild, and Stuart Hankin installed and maintained the weather stations and assisted with generating Fig. 1a. Regina Roach collected the fortnightly drip-water samples for this study. Monika Markowska performed the stable isotope sample analysis. Janece McDonald set up the drip-water monitoring study in 2006.

Acknowledgements. The authors are grateful to Suzanne Hollins for supporting this research. We thank Jagoda Crawford and Darrell Tremaine for useful discussion. Henri Wong, Chris Vardanega, Robert Chisari and Barbora Gallagher are thanked for their assistance with sample analysis. George Bradford and the staff at Yarrangobilly Caves and NSW NPWS are also thanked for their dedication and on-going field support and access permission. Silvia Frisia and Andrea Borsato are thanked for their assistance in the field regarding the geology of karst in the Snowy Mountains alpine region. Peter Briggs and Alan Griffiths are acknowledged for providing the AWAP data. PCT acknowledges the support of a Land \& Water Australia grant (project number ANU52) for this study. We thank Bill $\mathrm{Hu}$ and two anonymous reviewers for their constructive and thoughtful reviews that helped improved the manuscript.

Edited by: B. Hu

Reviewed by: two anonymous referees

\section{References}

Aplin, K., Ford, F., and Hiscock, P.: Early Holocene human occupation and environment of the southeast Australian Alps: New evidence for the Yarrangobilly Plateau, New South Wales, in: Altered Ecologies: Fire, Climate and Human Influence on Terrestrial Landscapes, edited by: Haberle, S., Stevenson, J., Prebble, M., 187-212, 2010.

Atkinson, T. C.: Carbon dioxide in the atmosphere of the unsaturated zone: an important control of groundwater hardness in limestones, J. Hydrol., 35, 111-123, 1977.

Baker, A., Genty, D., and Fairchild, I. J.: Hydrological characterisation of stalagmite dripwaters at Grotte de Villars, Dordogne, by the analysis of inorganic species and luminescent organic matter, Hydrol. Earth Syst. Sci., 4, 439-449, doi:10.5194/hess-4-4392000,2000 .
Baldini, J. U. L., McDermott, F., and Fairchild, I. J.: Structure of the 8200 year cold event revealed by a speleothem trace element record, Science, 296, 2203-2206, 2002.

Baldini, J. U. L., McDermott, F., and Fairchild, I. J.: Spatial variability in cave drip water hydrochemistry: Implications for stalagmite paleoclimate records, Chem. Geol., 235, 390-404, 2006.

Barros, A. P. and Bowden, G. J.: Toward long-lead operational forecasts of drought: An experimental study in the Murray-Darling River Basin, J. Hydrol., 357, 349-367, 2008.

BoM: http://www.bom.gov.au/climate/enso/ (last access: 24 December 2015), 2015a.

BoM: http://www.bom.gov.au/climate/mwr/ (last access: 24 December 2015), 2015b.

Borsato, A., Frisia, S., Fairchild, I. J., Somogyi, A., and Susini, J.: Trace element distribution in annual stalagmite laminae mapped by micrometer-resolution X-ray fluorescence: Implications for incorporation of environmentally significant species, Geochim. Cosmochim. Ac., 71, 1494-1512, 2007.

Cai, W. and Cowan, T.: Evidence of impacts from rising temperature on inflows to the Murray-Darling Basin, Geophys. Res. Lett., 35, L07701, doi:10.1029/2008GL033390, 2008.

Callow, N., McGowan, H., Warren, L., and Speirs, J.: Drivers of precipitation stable isotope variability in an alpine setting, Snowy Mountains, Australia, J. Geophys. Res.-Atmos., 119, 3016-3031, 2014

Chubb., T. H., Siems, S. T., and Manton, M. J.: On the decline of wintertime precipitation in the snowy mountains of Southeastern Australia, J. Hydrometeorol., 12, 1483-1497, 2011.

Coleborn, K., Spate, A., Tozer, M., Anderson, M. S., Fairchild, I. J., MacKenzie, B., Treble, P. C., Meehan, S., Baker, A., and Baker, A.: Effects of wildfire on long-term soil $\mathrm{CO}_{2}$ concentration: implications for karst processes, Environ. Earth Sci., 75, 1-12, 2016.

Crawford, J., Hughes, C. E., and Parkes, S. D.: Is the isotopic composition of event based precipitation driven by moisture source or synoptic scale weather in the Sydney Basin, Australia?, J. Hydrol., 507, 213-226, 2013.

Cruz Jr., F. W., Burns, S. J., Jercinovic, M., Karmann, I., Sharp, W. D., and Vuille, M.: Evidence of rainfall variations in Southern Brazil from trace element ratios $(\mathrm{Mg} / \mathrm{Ca}$ and $\mathrm{Sr} / \mathrm{Ca})$ in a Late Pleistocene stalagmite, Geochim. Cosmochim. Ac., 71, 2250 2263, 2007.

CSIRO and Bureau of Meteorology: Climate Change in Australia Information for Australia's Natural Resource Management Regions: Technical Report, CSIRO and Bureau of Meteorology, Australia, 1-222, 2015.

Cuthbert, M. O., Baker, A., Jex, C. N., Graham, P. W., Treble, P. C., Andersen, M. S., and Acworth, R. I.: Drip water isotopes in semi-arid karst: implications for speleothem paleoclimatology, Earth Planet. Sci. Lett., 395, 194-204, 2014.

Dai, A., Fung, I. Y., and Del Genio, A. D.: Surface observed global land precipitation variations during 1900-1988, J. Climate., 10, 2943-2962, 1997.

Drever, J. I.: The Geochemistry of Natural Waters, Prentice-Hall Inc., Englewood Cliffs, NJ, 388 pp., 1982.

Dredge, J., Fairchild, I. J., Harrison, R. M., Fernandez-Cortes, A., Sanchez-Moral, S., Jurado, V., Gunn, J., Smith, A., Spötl, C., Mattey, D., Wynn, P. M., and Grassineau, N.: Cave aerosols: Dis- 
tribution and contribution to speleothem geochemistry, Quat. Sci. Rev., 63, 23-41, 2013.

Fairchild, I. J. and Treble, P. C.: Trace elements in speleothems as recorders of environmental change, Quat. Sci. Rev., 28, 449-468, 2009.

Fairchild, I. J., Borsato, A., Tooth, A. F., Frisia, S., Hawkesworth, C. J., Huang, Y., McDermott, F., and Spiro, B.: Controls on trace element (Sr-Mg) compositions of carbonate cave water: implications for speleothem climatic records, Chem. Geol., 166, 255269, 2000

Fairchild, I. J., Baker, A., Borsato, A., Frisia,S., Hinton, R. W., McDermott, F., and Tooth, A. F.: High-resolution, multiple traceelement variation in speleothems, J. Geol. Soc. London, 158, 831-841, 2001.

Fairchild, I. J., Smith, C. L., Baker, A., Fuller, L., Spötl, C., Mattey, D., and McDermott, F.: Modification and preservation of environmental signals in speleothems, Earth Sci. Rev., 75, 105-153, 2006.

Frappier, A. B.: Masking of interannual climate proxy signals by residual tropical cyclone rainwater: Evidence and challenges for low-latitude speleothem paleoclimatology, Geochem. Geophys. Geosyst., 14, 3632-3647, doi:10.1002/ggge.20218, 2013.

Frisia, S., Borsato, A., Fairchild, I. J., and Susini, J.: Variations in atmospheric sulphate recorded in stalagmites by synchrotron micro-XRF and XANES analyses, Earth Planet. Sci. Lett., 235, 729-740, 2005.

Frisia, S., Borsato, A., and Susini, J.: Synchrotron radiation applications to past volcanism archived in speleothems: An overview, J. Volcanol. Geoth. Res., 117, 96-100, 2008.

Goede, A., McCulloch, M., McDermott, F., and Hawkesworth, C.: Aeolian contribution to strontium and strontium isotope variations in a Tasmanian speleothem, Chem. Geol., 149, 37-50, 1998.

Hartland, A., Fairchild, I. J., Lead, J. R., Borsato, A., Baker, A., Frisia, S., and Baalousha, M.: From soil to cave: Transport of trace metals by natural organic matter in karst dripwaters, Chem. Geol., 304-305, 68-82, 2012.

Hughes, C. E. and Crawford, J.: Spatial and temporal variation in precipitation isotopes in the Sydney Basin, Australia, J. Hydrol., 489, 42-55, 2013.

Hurst, H.: Methods of long-term storage in reservoirs, T. Am. Soc. Civ. Eng., 116, 519-543, 1951.

Jo, K., Kyung, S., Gi, H., Kim, S., and Suk, B.: Rainfall and hydrological controls on speleothem geochemistry during climatic events (droughts and typhoons): an example from Seopdong Cave, Republic of Korea, Earth Planet. Sci. Lett., 295, 441-450, 2010.

Johnson, K., Hu, C., Belshaw, N., and Henderson, G.: Seasonal trace-element and stable-isotope variations in a Chinese speleothem: the potential for high-resolution paleomonsoon reconstruction, Earth Planet. Sci. Lett., 244, 394-407, 2006.

Lauritzen, S. E. and Lundberg, J.: Speleothems and climate: A special issue of the Holocene, Holocene, 9, 643-647, 1999.

Markowska, M., Baker, A., Treble, P. C., Andersen, M. S., Hankin, S., Jex, C. N., Tadros, C. V., and Roach, R.: Unsaturated zone hydrology and cave drip discharge water response: Implications for speleothem paleoclimate record variability, J. Hydrol., 529, $662-675,2015$.
McDonald, J., Drysdale, R., and Hill, D.: The 2002-2003 El Niño recorded in Australian cave drip waters: Implications for reconstructing rainfall histories using stalagmites, Geophys. Res. Lett., 31, L22202, doi:10.1029/2004GL020859, 2004.

McGowan, H. A., Marx, S. K., Denholm, J., Soderholm, J., and Kamber, B. S.: Reconstructing annual inflows to the headwater catchments of the Murray River, Australia, using the Pacific Decadal Oscillation, Geophys. Res. Lett., 36, L06707, doi:10.1029/2008GL037049, 2009.

Murphy, B. F. and Timbal, B.: A review of recent climate variability and climate change in Southeastern Australia, Int. J. Climatol., 28, 859-879, 2008.

Nagra, G., Treble, P. C., Andersen, M. S., Fairchild, I. J., Coleborn, K., and Baker, A.: A post-wildfire response in cave dripwater chemistry, Hydrol. Earth Syst. Sci., 20, 2745-2758, doi:10.5194/hess-20-2745-2016, 2016.

Nicholl, O.: Harrie Wood Cave Map - Y26, Yarrangobilly Research Group and Canberra Speleological Society, Canberra, 1974.

Nicholls, N.: Local and remote causes of the southern Australian autumn-winter rainfall decline, 1958-2007, Clim. Dynam., 34, 835-845, 2010.

Oster, J. L., Montañez, I. P., and Kelley, N. P.: Response of a modern cave system to large seasonal precipitation variability, Geochim. Cosmochim. Ac., 91, 92-108, 2012.

Partin, J. W., Cobb, K. M., Adkins, J. F., Tuen, A. A., and Clark, B.: Trace metal and carbon isotopic variations in cave dripwater and stalagmite geochemistry from northern Borneo, Geochem. Geophys. Geosyst., 14, 3567-3585, doi:10.1002/ggge.20215, 2013.

Pook, M. J., Risbey, J. S., and McIntosh, P. C.: A comparative synoptic climatology of cool-season rainfall in major grain-growing regions of southern Australia, Theor. Appl. Climatol., 117, 521533, 2014.

Power, S. B. and Smith, I. N.: Weakening of the Walker Circulation and apparent dominance of El Niño both reach record levels, but has ENSO really changed?, Geophys. Res. Lett., 34, L18702, doi:10.1029/2007GL030854, 2007.

Raupach, M. R., Briggs, P. R., Haverd, V., King, E. A., Paget, M., and Trudinger, C. M.: Australian Water Availability Project (AWAP): CSIRO Marine and Atmospheric Research Component: Final Report for Phase 3. CAWCR, Technical Report No. 013, 67 pp., 2009.

Raupach, M. R., Briggs, P. R., Haverd, V., King, E. A., Paget, M., and Trudinger, C. M.: Australian Water Availability Project. CSIRO Marine and Atmospheric Research, Canberra, Australia, http://www.csiro.au/awap (last access: 15 November 2015), 2011.

Riechelmann, D. F. C., Schroder-Ritzrau, A., Scholz, D., Fohlmeister, J., Spotl, C., Richter, D. K., and Mangini, A.: Monitoring Bunker Cave (NW Germany): A prerequisite to interpret geochemical proxy data of speleothems from this site, J. Hydrol., 409, 682-695, 2011.

Risbey, J. S., Pook, M. J., McIntosh, P. C., Wheeler, M. C., and Hendon, H. H.: On the remote drivers of rainfall variability in Australia, Mon. Weather Rev., 137, 3233-3253, 2009.

Roberts, M., Smart, P., and Baker, A.: Annual trace element variations in a Holocene speleothem, Earth Planet. Sci. Lett., 154, 237-246, 1998.

Rozanski, K., Araguas-Araguas, L., and Gonfiantini, R.: Isotopic patterns in modern global precipitation, in: Climate Change in 
Continental Isotopic Records, edited by: Swart, P. K., Lohmann, K. C., McKenzie, J., and Savin, S., American Geophysical Union, Geophysical Monograph No. 78, Washington, D.C., 136, 1993.

Rutlidge, H., Baker, A., Marjo, C. E., Andersen, M. S., Graham, P. W., Cuthbert, M. O., Rau, G. C., Roshan, H., Markowska, M., Mariethoz, G., and Jex, C. N.: Dripwater organic matter and trace element geochemistry in a semi-arid karst environment: Implications for speleothem paleoclimatology, Geochim. Cosmochim. Ac., 135, 217-230, 2014.

Sinclair, D. J., Banner, J. L., Taylor, F. W., Partin, J., Jenson, J., Mylroie, J., Goddard, E., Quinn, T., Jocson, J., and Miklavic, B.: Magnesium and strontium systematics in tropical speleothems from the Western Pacific, Chem. Geol., 294, 1-17, 2012.

Spötl, C., Fairchild, I. J., and Tooth, A. F.: Cave air control on dripwater geochemistry, Obir Caves (Austria): Implications for speleothem deposition in dynamically ventilated caves, Geochim. Cosmochim. Ac., 69, 2451-2468, 2005.

Stern, H., de Hoedt, G., and Ernst, J.: Objective classification of Australian climates, Australian Meteorological Magazine, 49, 87-96, 2000.

Tooth, A. F. and Fairchild, I. J.: Soil and karst aquifer hydrological controls on the geochemical evolution of speleothem-forming drip waters, Crag Cave, southwest Ireland, J. Hydrol., 273, 5168, 2003.
Treble, P., Shelley, J. M. G., and Chappell, J.: Comparison of high resolution sub-annual records of trace elements in a modern (1911-1992) speleothem with instrumental climate data from southwest Australia, Earth Planet. Sci. Lett., 216, 141-153, 2003.

Treble, P. C., Fairchild, I. J., Griffiths, A., Baker, A., Meredith, K. T., Wood, A., and McGuire, E.: Impacts of cave air ventilation and in-cave prior calcite precipitation on Golgotha Cave dripwater chemistry, southwest Australia, Quaternary Sci. Rev., 127, 6172, doi:10.1016/j.quascirev.2015.06.001, 2015.

Treble, P. C., Fairchild, I. J., Baker, A., Meredith, K. M., Andersen, M. S., Salmon, S. U., Bradley, C., Wynn, P. M., Hankin, S., Wood, A., and McGuire, E.: Roles of bioproductivity, transpiration and fire in a nine-year record of cave dripwater chemistry from southwest Australia, Geochim. Cosmochim. Ac., 184, 132150, doi:10.1016/j.gca.2016.04.017, 2016.

Tremaine, D. M. and Froelich, P. N.: Speleothem trace element signatures: A hydrologic geochemical study of modern cave dripwaters and farmed calcite, Geochim. Cosmochim. Ac., 121, 522545, 2013.

Worboys, G.: Kosciuosko National Park Geology and Geomorphology, National Parks and Wildlife Service, Sydney, 1-26, 1982.

Wynn, P. M., Fairchild, I. J., Baker, A., Baldini, J. U., and McDermott, F.: Isotopic archives of sulphate in speleothems, Geochim. Cosmochim. Ac., 72, 2465-2477, 2008. 